\title{
Hosting the Dead: Forensics, Ritual and the Memorialization of Migrant Human Remains in Italy
}

Vanessa Grotti and Marc Brightman

\begin{abstract}
In this chapter we consider the afterlife of the remains of unidentified migrants who have died while attempting to cross the Mediterranean from Albania and North Africa to Italy. Drawing on insights from longterm, multi-sited field research, we outline paths taken by human remains and consider their multiple agencies and distributed personhood through the relational modalities with which they are symbolically and materially engaged at different scales of significance. The rising number of migrant deaths related to international crossings worldwide, especially in the Mediterranean, has stimulated a large body of scholarship, which generally
\end{abstract}

This chapter is based upon research carried out with the support of several grants: EU Border Care (2015-2020), funded by the ERC (ERC-2014-StG 638259); a Leverhulme Research Fellowship (RF-2016-602) and a EURIAS Fellowship (2017-2018) on migration and rural regeneration in Sicily; and a joint project funded by the Wenner-Gren Foundation, on unidentified migrant death and mourning in Italy (2018-2020). The arguments presented in this

V. Grotti $\bullet$ M. Brightman $(\bowtie)$

Department of Cultural Heritage, University of Bologna, Bologna, Italy

e-mail: vanessa.grotti@unibo.it; marcandrew.brightman@unibo.it

(C) The Author(s) 2021

V. Grotti, M. Brightman (eds.), Migrant Hospitalities in the

Mediterranean, https://doi.org/10.1007/978-3-030-56585-5_4 
relies upon a hermeneutics of secular transitional justice and fraternal transnationalism. We explore an alternative approach by focusing on the material and ritual afterlife of unidentified human remains at sea, examining the effects they have on their hosting environment. The treatment of dead strangers (across the double threshold constituted by the passage from life to death on the one hand and the rupture of exile on the other) raises new questions for the anthropology of death. We offer an interpretation of both ad hoc and organized recovery operations and mortuary practices, including forensic identification procedures, and collective and single burials of dead migrants, as acts of hospitality. Hosting the dead operates at different scales: it takes the politically charged form of memorialization at the levels of the state and the local community; however, while remembrance practices for dead strangers emphasize the latter's status as a collective category, forensic technologies of remembrance are directed toward the reconstruction of (in)dividual personhood. These ritual and technological processes of memorialization and re-attachment together awaken ghosts of Italian fascism and colonialism.

Keywords Italy $\bullet$ Death $\bullet$ Mourning $\bullet$ Mortuary practices $\bullet$ Migration

- Mediterranean $\bullet$ Hospitality $\bullet$ Forensics $\bullet$ Memorialization $\bullet$ Colonialism • Personhood

chapter are based on a total of 11 months of ethnographic fieldwork conducted in Italy from 2016 and in Albania in 2019. Conducting field research in Albania added a necessary and inspiring comparative frame to the more contemporary migrant shipwrecks. For motives of anonymity and space, we cannot thank individually the multitude of actors, survivors and respondents we met throughout the years. We are immensely grateful to all of our friends and acquaintances who participated in the research, as well as to Nataša Gregorič Bon, Maja Petrović-Šteger, Juliana Vera and Naor Ben-Yehoyada for their comments and suggestions, and to all those who participated in the "Ecologies of Remembrance" workshop organised by Naor Ben-Yehoyada, Bryan Boyd and Zoë Crossland on the 11-12 September 2019 at Columbia University (New York) and at the Anthropology Seminar of the University of Manchester on 7 November 2019. An earlier version of the chapter was published in French in L'Homme, and we thank the editors for permission to translate and republish the text here. 
Maj’ e Llogarasë mbi Vlorë Frynë er' e mbanë shumë bore, Ditën gë është mbytë anija Çoçë ka pare nuk e tregonë I flet Llogaraja detit:

- $O$ deti me kaltërsi!

Pse gjysmit na i dërgove

Ca I mban pengje në gji?
The top of Llogaraja mountain over Vlora

Which is blown by [strong] winds and can bear much snow

On that day, the ship was sunk

It has seen something but does not dare to tell.

Llogara speaks to the sea:

- O azure sea!

Why did you send us back only half [of the people]

And the rest you keep hostage in your bosom?

Maje e Llogarasë mbi Vlorë, migration song for Otranto, multipart group of Gumenica, 2009 (Pistrick 2015) $)^{1}$

\section{INTRODUCTION}

On 3 October 2018, the mayor of the island of Lampedusa² Totó Martello stood aboard a fishing boat, accompanied by survivors and relatives of the migrant boat disaster that had occurred exactly five years previously. Next to Martello stood a survivor holding a commemorative wreath destined to be thrown in the water, above the sunken wreck, which is still resting on the seabed, hardly recognizable beneath the coral now encrusting it. In the early hours of 3 October 2013, a fishing boat which had left two days before from Misurata (Libya) carrying over 500 passengers (mostly originating from a former Italian colony in the Horn of Africa, Eritrea) caught fire and sank close to a small rock off Lampedusa ${ }^{3}$ called Isola dei Conigli. The boat capsized as the passengers rushed to escape the flames and sank abruptly, creating a vortex which sucked most of the passengers who had succeeded in abandoning the vessel down into the depths. An estimated 366 people died in a matter of minutes. A few days later, on 11 October 2013, a second boat, carrying mostly Syrian refugees, sank in Maltese waters between Libya and Lampedusa, raising the number of victims by a further 280. The scale and high visibility of both events, often referred to together as the 3rd October tragedies, taking place at Europe's gateway, triggered intense but short-lived responses on the Italian and European political scenes. The survivors and relatives of the victims of the shipwrecks take part in an annual commemoration in early October on Lampedusa, where the recovery operations were based and the remains of the first shipwreck were initially transported. ${ }^{4}$ In March 2016 the Italian senate issued a decree making the 3rd October National Day of Remembrance and Hospitality (Giornata della Memoria e dell'Accoglienza), 
commemorating 'all victims of migration who die in the Mediterranean and in other international borderlands as they attempt to seek protection and a better future' (decree 45/2016). ${ }^{5}$ Every year, several thousands of visitors, including survivors, researchers, journalists and activists, flock to Lampedusa to accompany the relatives of the deceased and the disappeared in the commemorative events which unfold over almost a week.

The 3rd October tragedies are part of a series of large-scale maritime migration disasters that have occurred in the Mediterranean waters in Italy's orbit of influence since the 1990s, punctuating the history of Mediterranean migration with flurries of national and international attention from news media and political institutions. Three events stand out in particular: the first is the sinking of the Kateri i Radës, a vessel carrying families fleeing political violence in Albania, in the Strait of Otranto on 28 March 1997. We have chosen to frame our chapter with the additional comparative dimension of the Kateri i Radës sinking because it highlights connections necessary to understand what is at play in today's shipwrecks, in terms of the responsibility of the state, the relationship between scales and the divergent meanings of identification, repatriation and inhumation. The two other shipwrecks both involved vessels originating in North Africa: the 3rd October tragedies and an even larger disaster which occurred on 18 April 2015. Besides playing a distinctive role in collective memory, both in 'sending' countries and in the 'host' nation of Italy, these events are connected by three further features: firstly, the procedures of maritime recovery and in particular the large-scale and technically innovative recoveries of wrecks from deep water that took place in 1997 and 2016; secondly, the forensic identification procedures, which involved some of the same actors in the three cases; and thirdly, the subsequent rituals and materiality of memorialization, which occur at different scales, among relatives, in the communities where the deceased are buried, and at the level of the state.

The 2018 commemoration in Lampedusa was heavily mediatized, as it is every year, but on this occasion, it was particularly tense and polemical. For the first time since 2013, no representative of the central government attended the commemorations; to add insult to injury, the Italian Ministry of Education, University and Research (MIUR) cancelled the funding that it had approved under the previous administration through the $3 \mathrm{rd}$ October decree to enable schoolchildren to come from across Europe to participate in educational activities within the school in Lampedusa around the theme of migration and remembrance. In this heavily charged context, 
Martello refused to board the vessel of the national coastguard, choosing instead to join some of the survivors aboard a fishing boat to participate in the ritual launch of a wreath of flowers into the water to commemorate the dead.

Despite having been elected in 2017 on a stricter immigration agenda than his predecessor Giusi Nicolini, Martello spoke critically of Italy's new government ${ }^{6}$ and the drastic decision taken by its new far-right minister of the interior, Matteo Salvini, to close off all Italian harbors to rescue boats:

We are here today to recall a tragic event, many tragic events, and the answer we receive from Italy, but also from Europe, is silence; it is the attempt to erase even recent history. So, when they ...tell me that the projects to invite European schools [are not funded], there was no time, for me this says a lot. This is an attempt to prevent the transmission of ideas... of history, remembrance, memory...this is their attempt, with regard to Lampedusa, to cancel 'the problem'. Because it is not possible to carry on repeating in Italy that the 'problem' of the boat arrivals is over, that the problem of repatriations is over, that everything has been fixed, that no one dies anymore in the Mediterranean. Coming to Lampedusa, you realise the harbour is open, the boats with migrants come here directly... Why are they not telling the truth? Why are they trying to cancel remembrance and memory? ...If this nation is republican and democratic, as enshrined in the constitution, truth and respect for democratic rule have to be upheld... The Day of Hospitality and Remembrance is not a crime, it was approved and enshrined in law by the Italian Parliament, they want to make it a crime, so I say why can't Europe recognise the 3rd October as a day for the whole continent? So, the message which has to emerge from Lampedusa today is this: remembrance yes...but also fight...to respect ideas, democracy and freedom for all. (Totó Martello, $3 / 10 / 2018)^{7}$

By declaring that 'the harbor is open' in his official speech, Martello was expressing an ethical stance of hospitality and remembrance effective across several scales: Lampedusan, Mediterranean and of the Italian Republic. But on whose behalf? By criticizing 'political powers' and by refusing for the first time to board a boat belonging to and representing the state, by throwing the wreath from a Lampedusan fishing boat and by recalling the importance of history, memory and education, he positioned himself as an authority operating on a different time and scale than that of central government. His political statement sought a kind of affective resonance with a deeper historical consciousness. In his speech, the mayor 
from Lampedusa, wearing his fascia tricolore bearing the colors of the Italian flag across his chest, established his political legitimacy by anchoring Lampedusa at the heart of the Mediterranean and connecting its social and material landscape to collective processes of historical remembrance with strong connections to the post-war establishment of the Italian Republic, resistance and anti-fascism. In the context of the ritual enactments described above, his words illustrate a structural, long-term process which compresses time, space and social relations and which, as we shall see, rests upon specific forms of sociality, community activism, acts of hospitality, exchange and remembrance, around a language of intimacy and forensic 'technolog(ies) of remembering' (Wagner 2013: 633).

This process creates a special resonance between hospitality and death, in which choosing to welcome people who have escaped from death revives the national trauma of Italy's fascist past. Memorials and acts of memorialization of the dead and (from the opposite end of the political spectrum) counter-memorials such as a refusal to participate, or the desecration of tombs, lends the treatment of migrant death echoes of the contested territory of the Italian Republic's constitutional association with liberation from fascism. These echoes tend, however, to eclipse a deeper historical resonance connecting Mediterranean migration to the fascist regime-this is of course Italy's colonial past. ${ }^{8}$ As postcolonial Italian commentators have observed, Italy's colonial legacy and moral responsibility toward some of the sending and transit countries such as Albania, Eritrea, Somalia or Libya are seldom tackled in public and political activist discourse on migrant hospitality (Scego and Bianchi 2014); indeed colonialism and its legacy are rarely discussed publicly in Italy at all (Brioni and Bonsa Gulema 2018). By considering the ways in which hospitality may be offered to the dead themselves, we shall further explore these historical resonances, and we will end by arguing that hosting the dead recalls the legacy of fascism and colonialism, through memorialization and forensic recomposition of (in)dividual persons.

Hospitality is generally discussed as a practice that concerns the living; after all, it is assumed, a visitor or guest is an autonomously mobile agent, a sentient being. Yet anthropologists have long demonstrated that the dead are often far from inert; and while this seems a more obvious point in regard to spirits, ghosts or jinni (Varley and Varma 2018), it should also be considered in light of numerous discussions of the agentivity of material objects, whether as 'actants' to be understood as part of social networks alongside living beings or as enduring aspects of personhood (Tung 
2014). The potency, in more than symbolic terms, of the materiality of the dead, has been thoroughly explored by anthropologists, whose interest has nonetheless been mostly restricted to cases in which the deceased are community members (e.g. Bloch and Parry 1982). This is largely true even of the important work that has been done on mass graves and exhumations, which has nevertheless identified many themes that are relevant here, such as the role of forensics or legal medicine, both in searching for material evidence of crime and in the effort to restore individual personhood, the significance for transnational human rights and transitional justice and the role of social memory (e.g. Ferrándiz and Robben 2015). As with the present case, forensic and humanitarian exhumation has been recognized as not only 'part of a tradition of judicial inquiry' but also as 'a necessary step in the completion of funerary ritual' (Crossland 2015: 242). Despite these resonances, unidentified migrant death and the associated mortuary practices raise unique questions because they are cases of inhumation (not exhumation) of foreign bodies, and burial makes them more rather than less visible; the local community and the local landscape absorb them rather than rejecting them. It is for this reason that we can speak here of 'hosting the dead', where burial can be an act of hospitality.

The fact that mortuary practices may adapt to and express social change is well established (Geertz 1957; revisited by Boret et al. 2017) and reiterated in most emerging work on migrant death, which focuses on death within migrant communities in host countries (Hunter and Ammann 2016). Ethnographic accounts of migrant death and burial provide vivid and valuable insight into the emotional subjectivities of companions and survivors (Kobelinsky 2019), contributing to demonstrating the injustice of border death. But the mortuary treatment of dead strangers involves innovations that raise specific problems for anthropology. By discussing these in the framework of hospitality, we seek to examine the specificities of relationships between host communities and dead strangers.

Since 2017, we have visited a number of the dozens of municipal cemeteries in Sicily and Calabria in which the migrants who died at sea are buried. Without giving a detailed account, it is possible to outline some patterns that emerged. ${ }^{9}$ Religious leaders such as the imam of Catania and president of the Islamic community of Sicily, the Methodist pastor of Scicli and the parish priest of Cava d'Aliga told us how imams, Catholic, Protestant and, in some cases (especially when Eritrean migrants were involved), Coptic priests had worked together to devise 
non-denominational ceremonies to pray for the dead in cities such as Catania, Siracusa and Scicli. Those involved in the burial ceremonies, including priests and custodians of cemeteries, discussed tenderly the ways the bodies were positioned (if possible, with the face or head toward Mecca in the case of Muslims), the problems of trying to find spaces and the readiness with which local people spontaneously donated clean sheets in which to wrap the bodies (the wife of the mayor of Pozzallo is said to have donated the sheets in which her first child had been wrapped following the birth, newly washed and starched). The custodian of the cemetery of Palazzolo Acreide described how the bodies of migrants from the October 2013 tragedy were buried by a single undertaker using a small crane, without any ceremony, yet he told us that the flowers on the grave were placed there by local widows, who extended their care beyond their own family tombs to those that lay untended. Such anonymous gestures were common to all of the cemeteries we visited. The local parish priest at Cava d'Aliga also described how he would regularly find little bamboo crosses and flowers on the beach at Sampieri, left by persons unknown. As Giorgia Mirto has commented to us (pers. comm. July 2019), ordinary local people do not see the deaths of migrants at sea as 'border deaths'; they merely see them as poor unfortunate souls who met an untimely end and who, being far from home, have no one to mourn for them at their graves. They adopt them as their own, even sometimes referring to them as 'sangu meu', my kin (lit. 'my blood'). Others at the 'front line', such as police officers and priests, similarly express compassion rather than political judgment, but in their reflections, they refer more readily to the memory of how caring for strangers, dead or alive, was a way of responding to violence. The Methodist priest in Scicli even referred to the story of local residents donating a ship to the town's Jewish community to allow them to escape the island during the Spanish Inquisition. Beyond our interviews with these key actors, our interest in memory and time in this chapter is directly inspired by our immersion in local communities whose identities, keenly aware of their Greek, Arab, Norman and Spanish heritage in the case of Sicilians and of their Greek and Albanian heritage for Calabrians, are stronger than their concern with Italian nationality or border policies. These local identities, together with senses of pious compassion shared by Catholics and the much smaller Protestant and Muslim communities, evoke temporal more than spatial perspectives, paying scant attention to geopolitical events. Here, compassion for the weak is not an expression of transnational fraternity (unlike humanitarianism), and care for the weak or 
the dead is expressed in terms of vertical consanguinity (parent-child relations).

In contrast to anthropological accounts of mass graves and exhumations, ethnographers of migrant death have paid surprisingly little attention to materiality, despite the fact that it has unique importance in the case of dead strangers, for here the material aspects may well be 'all that remains' (Black 2018). If the dead community member is ritually reinstated as a part of the community (albeit sometimes relinquishing personal identity) and thus contributes to social reproduction, what happens to the material remains of a dead stranger, and what are the effects of their treatment? Does the multiplicity of bodies that results from mass death, which in other circumstances such as warfare may trigger specific international protocols for forensic identification and repatriation, define their treatment in systematic ways? What are the ritual consequences of forensic processing and local burial in the limbo of states' national and international disengagement? To consider such questions we turn to the maritime and forensic operations which have been improvised in recent years in Italy in order to locate, recover, identify and bury migrant human and material remains in the Central Mediterranean.

\section{Necropolitics and the Central Mediterranean Route}

The Central Mediterranean route is by all accounts the deadliest international crossing in the world, in terms of both absolute numbers and the magnitude of individual maritime disasters: of nearly 32,000 recorded migrant deaths worldwide between 2014 and 2019, over 15,000 have occurred on there (IOM 2019). Such estimates are necessarily conservative, since they are based on partial government statistics and media and NGO reports, and they do not include those who are lost at sea or in regions where data collection is virtually impossible due to lack of amenities (the Sahara Desert) or unrest (Libya), but where it is likely that the largest number of migrants die - the number of migrant deaths that occur in the Sahara desert is likely to be at least double those in the Mediterranean, according to the director of the IOM (Reuters 2017). Few countries in the world have a centralized and unified system in place for the systematic registration and identification (covering both ante- and postmortem logs) of unidentified remains which operates across state services and jurisdictions, from hospitals wards to police departments and morgues. In Europe, Italy is the only country to have established an office for the disappeared, 
the UCPS,${ }^{10}$ directly located in the Ministry of the Interior, and organized around a single database, known as the RISC (Ricerca Scomparsi), which centrally collects all reported unidentified corpses gathered on the territory-yet this initiative has only in recent years tentatively been extended to migrant bodies recovered during rescue operations at sea. This complicates the necessary international coordination across a multiplicity of state and non-state actors, a problem compounded by the fact that in international crossings, victims may be nationals of a country which prohibits emigration or lacks records.

The presence of emergency services and news media and the tense and critical conditions in which the crossing and rescues at sea take place have made the maritime crossing between Mediterranean shores (specifically from Libya, Tunisia and Egypt to Southern Italy) and migrant death at sea, into a spectacle, inspiring public and literary commentators to describe the Mediterranean as a 'cemetery' (Cattaneo 2018; Vatican News 2018) and a 'liquid grave' (Casid 2018; Sarnelli 2015). With each maritime disaster, the use of such terms has grown. But what does the analogy imply with regard to the fate of the remains of the victims? If the Mediterranean is a watery grave, whose grave is it and who is called to mourn and pacify the dead? How is a liquid transnational grave adorned, for whom and by whom? There is no obvious answer to these questions partly because the Mediterranean migrant dead are victims of a mass atrocity that is inadequately covered by international or humanitarian law-the legal obligations of states with regard to the remains of those who die on migration trails anywhere in the world are poorly defined (Last Rights 2017: 1). According to the Last Rights Project, the principles of human dignity already expressed in human rights law and in legal instruments such as the Geneva Conventions do entail duties on states to give proper burial to the remains of deceased migrants, but a legal void exists because such specific duties have not yet been formally codified. Italy itself enshrines the equality of treatment of citizens and non-citizens, including integrity in death, under article 10 of its constitution (Cattaneo and D'Amico 2016), but this article may also be open to divergent interpretations and is openly ignored or even challenged by the Italian government itself. Besides, the impetus to give respectful burial does not come from the law itself, as the Last Rights authors themselves emphasize, citing Sophocles' Antigone (in which the protagonist buries her brother in defiance of the wishes of the new king, Creon) to illustrate their assertion that respectful treatment of the dead is 'a principle incapable of being overridden by government' 
(Last Rights 2017: 2). ${ }^{11}$ They nonetheless continue to unquestioningly assume the existence of an agreed definition of respectful burial itself.

If the material aspects are all that remains of dead strangers, this has not prevented migration scholars from focusing instead upon the symbolic value of the sheer multiplicity of dead migrant, which often leads them to invoke Achille Mbembe's concept of 'necropolitics' or Giorgio Agamben's 'thanatopolitics' to highlight how the threat of death is enlisted as a tool for political control over international migration flows (Sarnelli 2015). Reports of migrant deaths can take the form of statistical accounts produced by organizations such as the International Organization for Migration (IOM), the International Red Cross and Red Crescent Movement, national naval authorities and some smaller international NGOs, activist groups or blogs ${ }^{12}$ or of migrants' own informal accounts in person or via social media. In all these cases, they often translate into an awareness of the possibility of death that is said to condition behaviordeath is instrumentalized as a deterrent to migration. De León introduces the notion of 'necroviolence' to characterize the way in which the Sonoran desert has become a place of violence toward which the infrastructure of the US-Mexico border directs migrants seeking to cross, to the extent that it is practically a war zone, where hostile nature is enlisted as a weapon (2015). Death and violence toward the other are construed in turn as constitutive of the host society itself: as Albahari writes, 'death, a prerogative of sovereignty, is one of the instruments by which liberal democracy is purportedly defended, and its life and common good fostered' (2015: 114).

De León's aggregating approach to evidence paints a largely uniform picture of a US border regime in which local agencies enact national policies with brutal efficiency. The evidence of migrant death in the Mediterranean suggests a more complex picture of diverse (human and nonhuman) agents (local, national, transnational) acting in different ways, in some cases aiming to challenge, subvert or attenuate the effects of border policies that are in many respects similar to the US. 'Naturalizing' border regions such as a desert or a sea produces a distancing and dehistoricizing effect on what are highly connected, transformative and living environments with a rich history and characteristic ecology of interspecies relations. Regions such as the Mediterranean are defined and alive through the sea, which, exceeding characterizations in terms of natural wilderness and hostility, is also perceived as a place of abundance, connectivity and regeneration; yet such peripheral regions have also been homogenized as living outside of modernity and located outside of time 
(Elhariry and Tamalet Talbayev 2018). Death itself is not merely caused by state regimes, it can take many guises in migration and migration itself is widely thought of by sending communities as a passage from life to death or from death to life. For instance, in Albania, migration, kurbet, is also known as 'black death', and the migrants' uprooting from home and family must be ritually mourned by the relatives (Gregorič Bon 2017). Moreover, just as the mistreatment or erasure of dead bodies can be used for political repression or control, forensics and burial can also sometimes be used for acts of resistance, through revelation, making events and histories visible. In the absence of an international agreement to allocate legal responsibility for migrants who die, the forensic analysis and burial of their remains, spring from impulses independent from, or opposed to, a dominant necropolitical discourse, drawing upon historical consciousness. In contrast to the humanitarian impetus behind international responses to natural disasters (Merli and Buck 2015), Italian legal scholars and forensic or medical legal practitioners justify their work in this area on constitutional grounds, arguing that dignified and respectful treatment of unidentified remains is a legal duty in Italy. ${ }^{13}$ We suggest that this is not merely a technical move, but rather it is part of a challenge to the assumption that 'languages of numbers, evidence, rights, the rule of law, exclusion, recognition, trauma and other related notions have a privileged grasp of reality compared with, say, the language of ritual' (Rojas-Perez 2017: 10). In fact, forensics can become part of the ritual treatment of the dead, and together with burial and mourning, they can also take on powerful political dimensions. A simplified chaîne opératoire (Lemonnier 1976) description of the treatment of migrant human remains in Italy would distinguish three main operations: firstly, the retrieval of the corpse from the sea (and in certain cases from the wreck); secondly, naming, through the forensic process of identification; and thirdly the provision of a resting place through burial. ${ }^{14}$ In the following sections, we will outline each of these stages and discuss their effects.

\section{Recovery Operations and Spatial Memory}

Remains of victims of migrant boat disasters can be recovered from the sea through a rescue operation (at high sea or near the shore), through salvage-type diving operations around shipwrecks, by incidental recovery at sea by a vessel (such as a fishing boat), or through a large-scale naval salvage operation to extract an entire wreck from the seabed and bring it 
to land. Italy is the only country to have launched two large-scale recoveries of sunken migrant ships. The first was ordered by a court in 1997, following the sinking of the Kateri i Radës in the Channel of Otranto, causing the deaths of 81 Albanians, including a majority of women and children. The victims of the 3 October 2013 disaster were successfully recovered by divers, but following a further mass disaster on 18 April 2015, when an Eritrean vessel sank in deep waters near the Libyan coast following a collision with a cargo vessel, with an estimated 1000 passengers on board, the Italian prime minister Matteo Renzi ordered a further large-scale recovery operation. These large-scale operations were highly mediatized, and to the consternation of xenophobic commentators, they publicly revealed the reality of these bodies formerly hidden on the seabed, as well as allowing subsequent forensic identification processes, thus extending the boundaries of conventional forensic work.

We began the chapter with an excerpt from a migration song recorded in 2009 by ethnomusicologist Eckehard Pistrick in southern Albania, during the local commemoration of the 1997 sinking of the Kateri i Radës. This event left deep and enduring emotional scars in Albania, where it is known as the 'Otranto tragedy' and for which the Italian navy was convicted (17 years later) for its culpable action, ramming the fishing boat as part of a blockade against a wave of migration from Albania. In this song, the mountain and the sea that are the principal features of the landscape of Vlora are brought to witness the death and disappearance of so many of the town's inhabitants. Pistrick describes how sensorial features of the landscape, such as the sound of the rushing water of a river, can generate emotional inspiration for remembrance and mourning through poetry and song. The living landscape inspires remembrance of the events it has witnessed. This applies as much to the mountain as it does to the sea, which refuses to return the bodies of the missing relatives. As Yael NavaroYashin has suggested, affect may emerge from the environment-a 'spatially effected melancholia' (2009: 5) and the 'subjectivities and residual affects that linger...in the aftermath of war or violence' (2009: 5). In this example, the most painful mourning is that which takes place in the absence of the body and in the knowledge that the sea retains those bodies (cf. Perl 2016). Some of the survivors and bereaved relatives we interviewed in Albania in 2019 felt deeply wounded by the proceedings of the recovery operations. Despite the fact that, in contrast to the shipwrecks on the Central Mediterranean route, the bodies recovered from the Kateri i Radës wreck in 1997 were returned to Albania, local stories abound about 


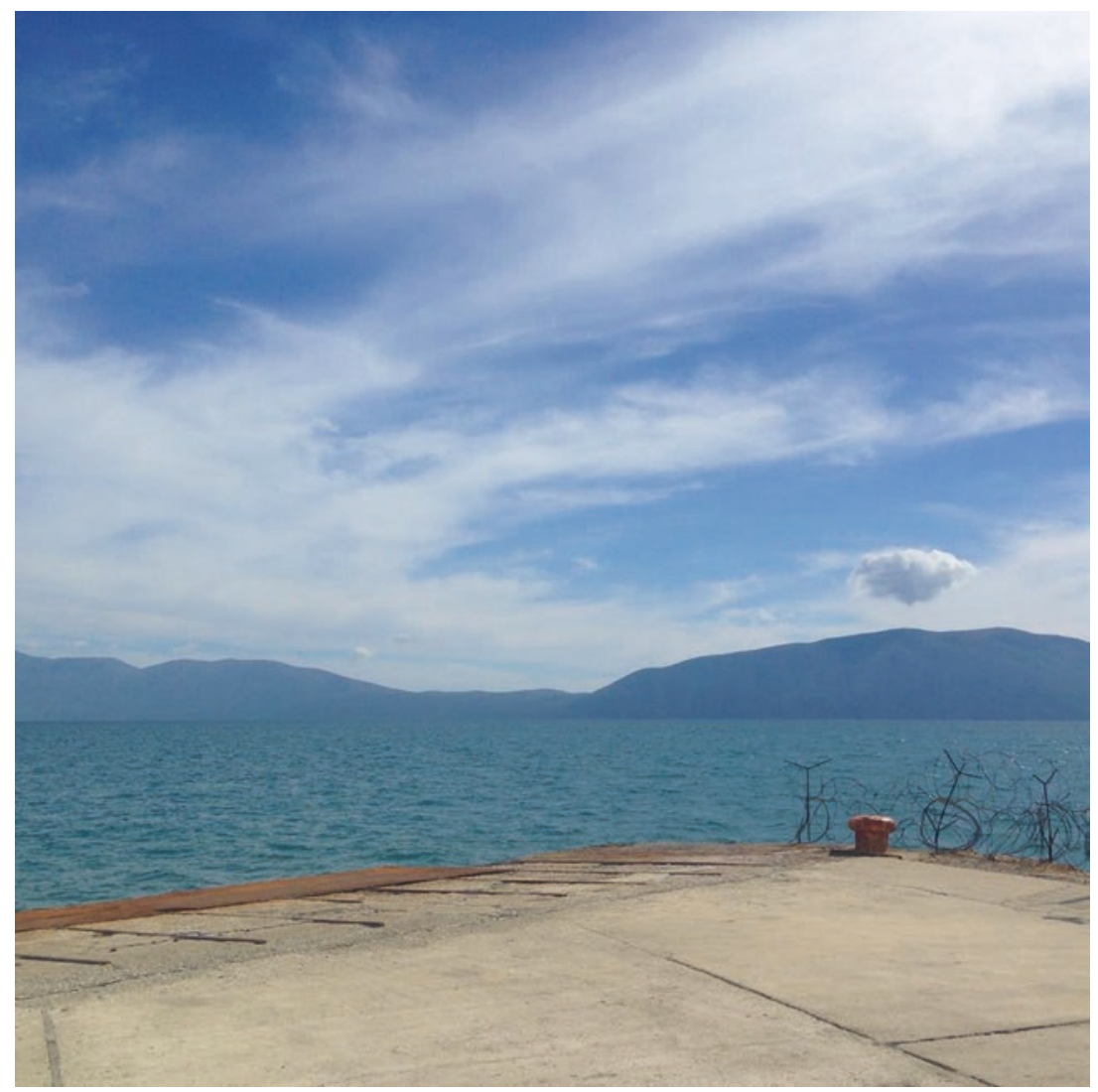

Fig. 4.1 The boarding dock of the Kateri i Radës at Vlora, which became the site of the annual commemoration of the Otranto Tragedy. Vlora, Albania, 2019 (photo by Vanessa Grotti)

how the 57 coffins that were buried in Vlora merely contain seaweed or that the body in the coffin had been irreparably damaged and tormented. As expressed in the inscriptions on some of the tombstones by their missing relatives (see Fig. 4.1), those buried in the cemetery are still suffering in the sea (Figs. 4.2 and 4.3).

This explains factual errors present in book-length features on the shipwreck, such as Alessandro Leogrande's book. It also illuminates the verses the words 'Why did you send us back only half [of the people]/And the 


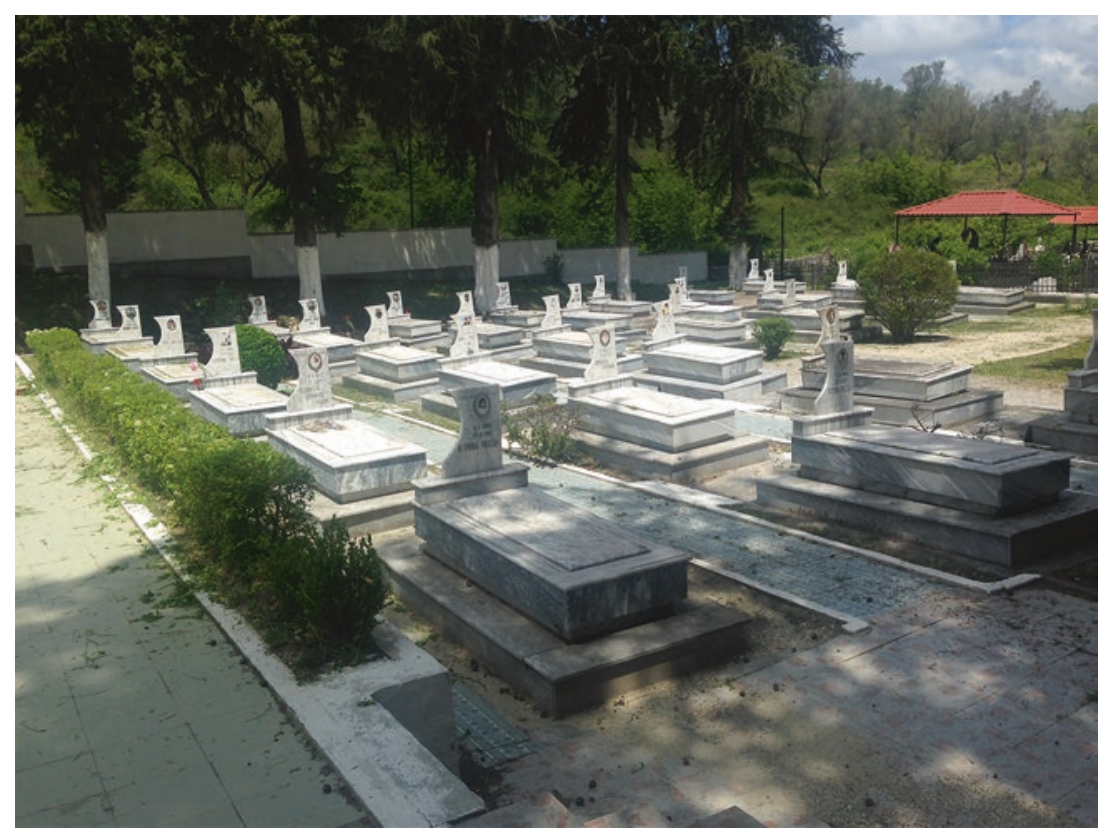

Fig. 4.2 Part of the Vlora cemetery dedicated to the victims of the Kateri i Radës wreck, Vlora, Albania, May 2019 (photo by Vanessa Grotti)

rest you keep hostage in your bosom?' carry a double meaning: they refer both to the fact that 57 coffins were returned for 81 missing people but also evoke a delayed return of bodies immersed in a watery limbo which altered body and soul and can therefore never be complete or provide a real sense of 'closure'. The 'canonical' mortuary practices involve dressing the body in new clothes and exposing it in the home for 24 hours, to allow relatives and friends to pay their respects and bear witness, and only such direct contact can establish the truth of the passage from life to death, especially in a country which remains intensely distrustful of institutions and government, even decades after the fall of the communist regime and its notorious state surveillance system. The recovery and return of human remains thus allow the state to wash its hands of a tragedy but only brings partial respite for mourning relatives. As Maja Petrovićčsteger so brilliantly demonstrated in her work on forensic identification and repatriation of human remains in post-conflict settings such as Ex-Yugoslavia and 


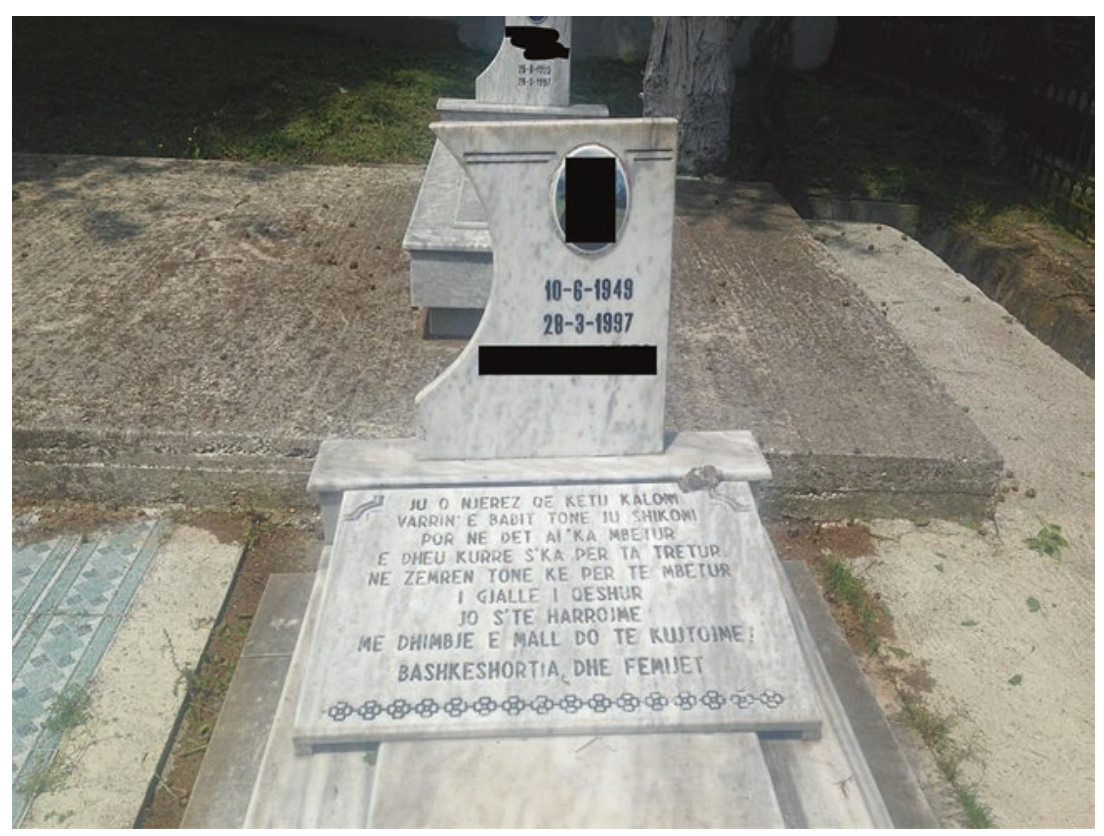

Fig. 4.3 Inscription on the tomb of a victim of the Kateri i Radës wreck, Vlora cemetery, Albania, May 2019 (photo by Vanessa Grotti). The inscription reads: You who are passing here by/the tomb of our father you are looking at/But, in the sea, he remained/And the soil will never waste [perish/tretur] him/In our heart, you'll always stay/Alive and smiling/No, we won't forget you/With pain and longing [mall]/ You'll be remembered./ Your spouse and children (translation courtesy of Nataša Gregorič Bon)

Tasmania, identification and return of human remains only partially resolve ambiguous loss for the relatives (2006a). ${ }^{15}$ Remains though carry a powerful meaning to those who handle and treat them, and this dimension carried potential for future research.

\section{Forensic INFrastructures AND AfFeCt}

Previous studies of the treatment of migrants who have died or gone missing in the Mediterranean have so far excelled in establishing databases and connecting separate initiatives dispersed across the region; they have also emphasized the suffering of the families of the deceased and the 
disappeared (Robins 2019; Stierl 2016). Tapella et al. (2016), through the Death at the Borders project, have provided an account of the bureaucratic processing of migrants' cadavers in Italian borders: records of the operations to retrieve bodies are to be found in the archives of different police forces (guardia costiera, guardia di finanza, carabinieri) depending on which agency was involved, and after the report reaches the public prosecutor's office (Procura della Repubblica), there is no standard procedure for the identification of the body. Autopsies are not routinely carried out, and a general examination of the corpse is often sufficient for a burial permit to be issued. Yet even after processing, bodies often remain for long periods in morgues without being buried, because local authorities claim not to know how to process the death certificate (atto di morte) which is a prerequisite to burial. Such attention to the bureaucratic processing of the dead, while valuable, risks giving a false impression that southern European nations are less well equipped to manage the anonymous dead and neglects the ritual dimensions of the phenomenon; after all these bureaucratic processes can be considered as ritual stages in their own right, and as such they highlight at once the ritual necessity of burying dead strangers and state institutions' lack of ritual expertise. They do not delve deeper into the local social worlds of borderlands and their unique material, legal and moral configurations, and they oddly neglect to mention some of the key players, notably the work of the Labanof (Laboratory of Forensic Anthropology and Odontology) of the University of Milan, ${ }^{16}$ which is the principle among a few institutions and agencies that have steadily worked for the recovery and identification of migrant remains in Italy over the past 25 years, initiating national and international protocols and databases for missing persons.

Mediterranean nations present a considerable variety of forensic identification processes and traditions and operate at highly differentiated institutional interfaces of judiciary, medical and maritime authorities. This complexity is illustrated by the Labanof institute's co-director Cristina Cattaneo's reflections on the lack of response among international forensic scientists immediately after the 3rd October disasters, which contrasted with the usual flurry of activity after a mass disaster such as an aeroplane crash or a tsunami:

Although I had allowed myself to be convinced lazily and a bit naively that it was another case of the usual racism, I felt that this did not tell the full story. The problem was much bigger. And the truth lay in the not only 
economic but above all technical difficulty of managing the biggest disaster of recent times, an enormous tragedy diluted in time and in space. (Cattaneo 2018: 28)

In other words, migrant deaths at sea had been occurring constantly since the 1990s, and the dramatic 3rd October tragedies merely made them more visible. That numbers of 'a tragedy diluted in time and in space' remain so hard to collect, verify and merge into one single reliable and protected international database is the primary illustration of the almost impossible task that forensic pathologists such as Cattaneo, or the operators of the International Red Cross in Italy, leading actors in the creation of unified protocols and databases for the national identification of anonymous human remains, have to grapple with on a daily basis. Cattaneo draws attention to the emotional and affective elements of these techniques and practices, which play a key role in the forensic process. As in the case of post-conflict former Yugoslavia and Guatemala, DNA sampling and forensic technologies do not merely act for the purpose of 'knowledge production, truth, and surveillance' on behalf of the state (Smith 2013: 1), but rather forensic techniques here acquire 'affective and sacred dimensions...imbued with an ethic of care' (Smith 2013: 1). The methods deployed include the likes of odontology and facial reconstruction and can scarcely rely on DNA testing:

[T] his is a technical prejudice... you cannot identify only with DNA. In this case there was this misunderstanding, this illusion that all we had to do was to collect some saliva from the mouth of the corpse without even having to open the bodybag... [which is useless without access to the DNA of close relatives] ...we have been using Facebook for the corpses which were well preserved to identify tattoos, beauty marks, scars, or simply the shape of the face. (Cattaneo in Ghidini 2018)

Such technologies can also be active tools in human rights activism and processes of memorialization (Anstett and Gatti 2018). Forensic identification procedures have transformative capacities which turn horrifying masses into separate piles of objects which, once reassembled, become distinct, named (or unnamed) victims to be mourned. ${ }^{17}$ Classification and reconstruction restore their personhood. As Cattaneo writes ' $[\mathrm{My}$ job is to] try to prevent forgetting, to get close (emotionally) and talk about what brings these people closer to us, that is finding in the pockets of these 
young people the same things we or our young people carry around ... is very useful to get closer and to mediate' (Cattaneo in Ghidini 2018). In this way, forensic scientists have described their work as a deeply emotional process of kinship-making, contrary to stereotypes, and more in line with anthropological understandings of kinship as the expression of multiple forms of relationship.

\section{Memorialization: The International Migrants' Cemetery}

The forensic work of reconstructing personhood from scattered material remains can be understood as an effort to interpellate the dead and allow them to speak, revealing truths that only they can tell. In its focus on the person and the material manifestations of relations of kinship, attachment and belonging, it contrasts with processes of memorialization, which tend to produce and reproduce collective entities, in this case, the collectivity of the dead at sea. Memorialization in public debate in Italy shares a moral impetus with the hosting of migrants, which is frequently connected to " $l a$ memoria', a shorthand for remembering those who resisted the fascist regime and its history of violence and repression, especially the racial laws and the deportation of Jews to concentration camps (Glynn and Kleist 2012: 8). These memories are evoked, or ignored, by different political factions to justify their position in regard to migrants, and fascism is invoked in terms of either resistance or nostalgia.

The symbolic resonance of the wreath used at the commemoration of the 3rd October tragedies is a good illustration of this. In Italy, wreaths are symbolically connected to the ritual celebrations of the 25th April, Liberation Day, which take place primarily in cemeteries and at monuments to the dead, from small municipal war memorials to the tomb of the unknown soldier (milite ignoto) at the Altar of the Nation (Altare della Patria) in Rome. Wreaths, as established state ritual objects, are used to commemorate a nation's dead and their sacrifice, for example, soldiers who died or went missing in combat and whose bodies could not be brought back. As Naor Ben-Yehoyada has noted, monuments like those dedicated to unknown soldiers commemorate an "entire category of persons' as "fraternal sacrifices...for the sake of a cause declared "national" (n.d.: 4). On the shores of the Mediterranean, various community traditions also commemorate local soldiers and migrants who die abroad (e.g. 
empty graves in former Yugoslavia, Pistrick 2015: 121), and, as we shall describe, there is an emerging practice of local remembrance for hosting foreign migrants who died en route to Italy. ${ }^{18}$

Cemeteries are prominent in the landscapes of Sicily and Calabria. Imposing walled enclosures filled with elaborately designed family tombs adorn the hills outside each town, often containing architectural gems that are overlooked by tourists more attracted by the ancient necropoli whose nameless denizens have long since vanished. Within the cemeteries, family tombs can be distinguished from confraternity tombs and communal ossuaries, and migrants, with known or unknown identities, have been buried in all three kinds, even on one occasion hosted within a family tomb (see Figs. 4.4 and 4.5). On Liberation Day, 25 April 2017, a ceremony was held in the small Calabrian town of Tarsia to present the project for the creation of an International Migrants' Cemetery, supported at the

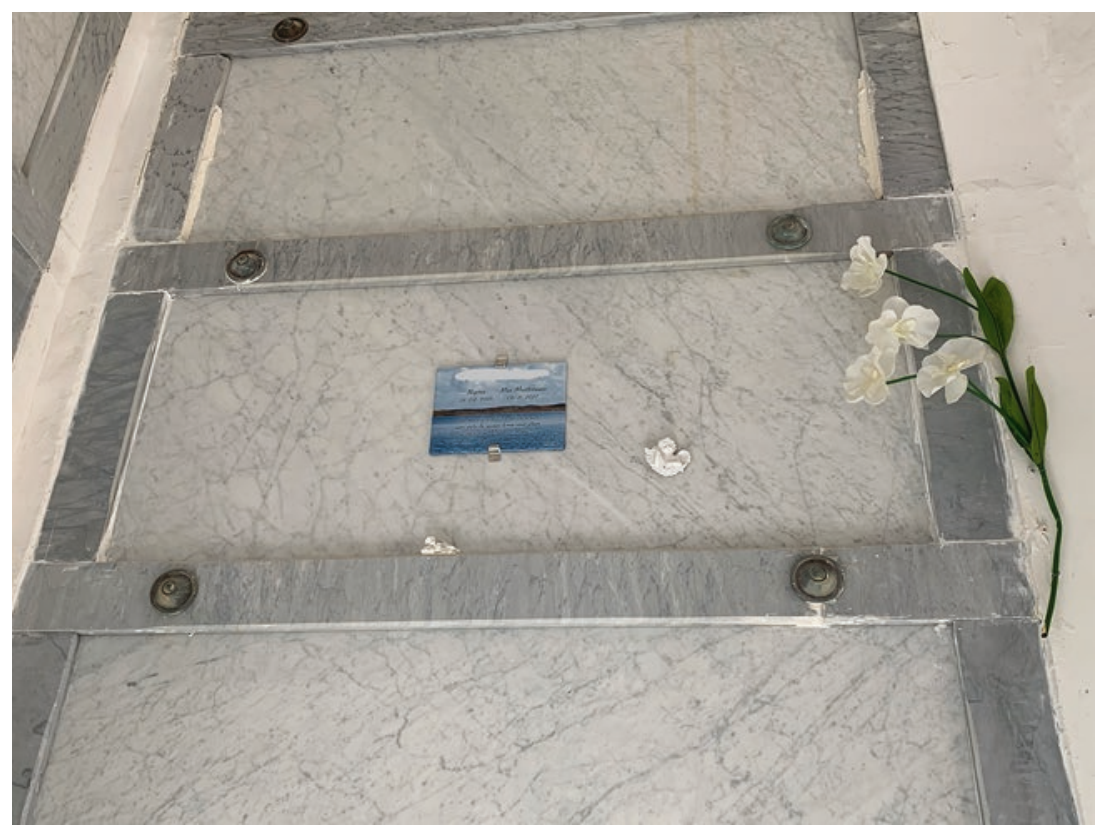

Fig. 4.4 Family tomb containing the remains of a Nigerian girl who lost her life in a wreck off the shore of Sampieri (Sicily) in 2017. Scicli, Italy, July 2019 (photo by Marc Brightman) 


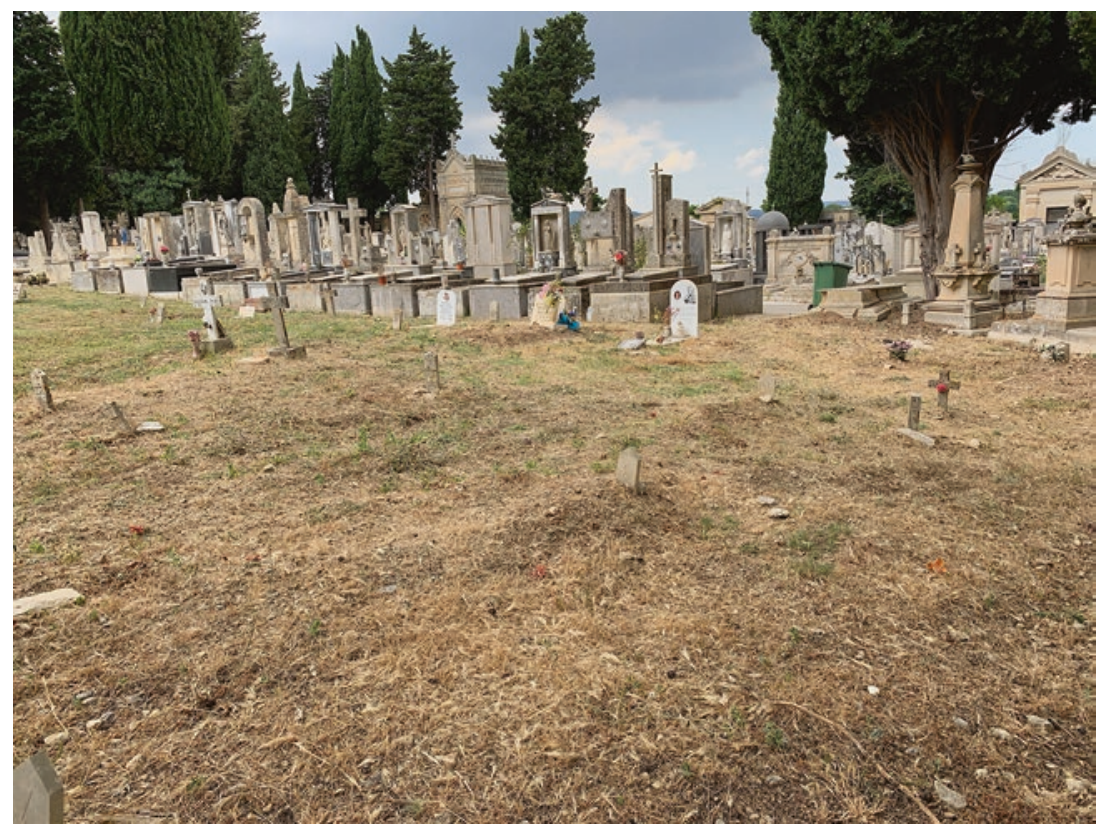

Fig. 4.5 Graves of unidentified migrants, victims of the 3 October 2013 wreck, Palazzolo Acreide, Italy, July 2019 (photo by Marc Brightman)

time by the Italian Ministry of the Interior and the Region of Calabria. The initiative is intended to provide a burial place for unidentified or unclaimed human remains recovered in Italian and international waters, which have hitherto been distributed among municipal cemeteries across Sicily and Calabria, sometimes in special extensions of the existing burial ground. It is meant to resolve the practical problem of giving a dignified burial to human remains after an often lengthy administrative process. During our meeting in late 2018 in a scrubby grove filled with ancient olive trees, on the slopes below the hilltop town, which is to be the site of the migrants' cemetery, the mayor of Tarsia Roberto Ameruso and the civil rights campaigner Franco Corbelli, who conceived and promoted the project, gave an impassioned performance, placing great emphasis on the concept of dignity-Corbelli sees the cemetery as 'restoring dignity to those who have lost their lives'. With relentless energy compensating for his diminutive appearance, Corbelli insistently set out his vision of a 


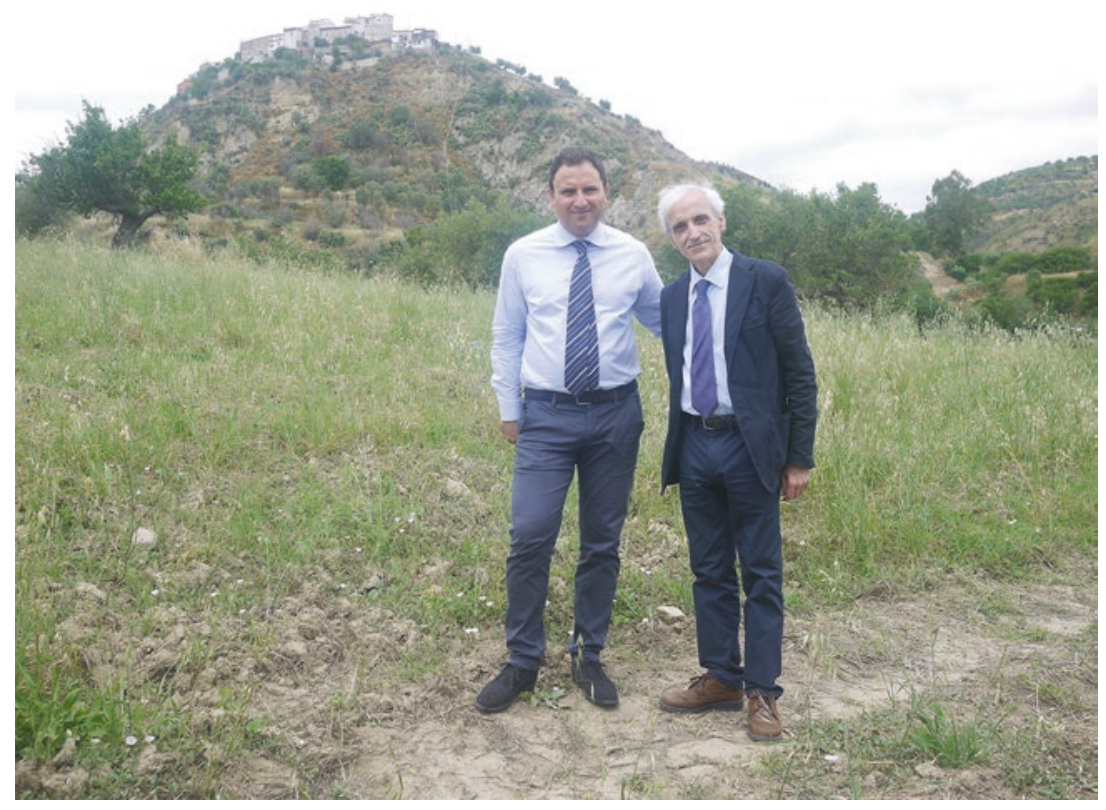

Fig. 4.6 Franco Corbelli and the mayor of Tarsia, Roberto Ameruso, on the site of the future migrants' cemetery, Tarsia, Italy, May 2018 (photo by Marc Brightman)

monument to peace, a counterweight to the politics of repression that is resurgent in the new government. He described how since the 3 October 2013, the cemetery had become an obsession for him, and before settling on the site in Tarsia with the local mayor and the regional governor, he planned to use a piece of land of his own for the purpose. He also drew attention to the cultural landscape - the picturesque location with the hilltop town above and the seasonal lake below-a protected area managed by Friends of the Earth (see Fig. 4.6).

The cemetery is not strictly intended as a final resting place: on the one hand, burial closes the Italian process of forensic documentation, completing its reconstruction of personhood of remains previously distributed across sites of analysis and storage spread across Italy. The organizers nevertheless hope that relatives may claim the dead at some time in the future, and their bodies may yet be exhumed and transported elsewhere. The 
cemetery thus provides a space for mourning ambiguously suspended in time.

The migrants' cemetery is a public statement reflecting humanitarian activism in Tarsia itself, and in the region of Calabria, as well as a previous Italian government's desire to emphasize its image as the front line of migration reception at a European level. ${ }^{19}$ At these different scales, these statements are aligned but not identical. For Tarsia and Calabria, it 'scales up' the local actions of a network of mayors opening small rural towns as 'migrant havens', welcoming refugees and asylum-seekers as part of a strategy supporting the repopulation and regeneration of ageing and poor communities with dwindling social services, and proclaims alignment with both secular and Catholic humanitarianism. But at a national level, the previous, center-left government's endorsement (together with the salvaging of the April 2015 shipwreck) promoted an image of the Italian state as a beacon of civilization in the Mediterranean, morally superior to other EU Member States as it shoulders the burden of the humanitarian crisis of migration - the cemetery is accordingly presented as being a place of burial for all migrants who perish at sea in the Mediterranean (although in practice only those who died on the route to Italy itself are very likely to end up there).

On both levels however, the initiative explicitly seeks a kind of affective resonance with a deeper historical consciousness, for the cemetery lies in close proximity to the site of Ferramonti, Italy's largest concentration camp from the Second World War (Fig. 4.7).

As the governor of Calabria, Mario Oliverio, said during the laying of the wreath at Ferramonti on 25 April 2019:

the migrants' cemetery is a symbol that is linked to that of the 25th April, and it is no coincidence that it was conceived and is being realised here. A symbol that respects human dignity, and the millions of men and women forced to cross the Mediterranean who sometimes lose their lives. And dignity must also be respected for those who lose their lives. (Qui Cosenza 2019)

Ferramonti evokes the emergence of the postwar moral and institutional order through the shock of the evidence of the holocaust and thereby claims that the national and international institutions responsible for upholding this moral order-governments with internationally agreed human rights enshrined in their constitutions-should claim migrant deaths 'as their own'. Tarsia might offer interpretation as a form of 


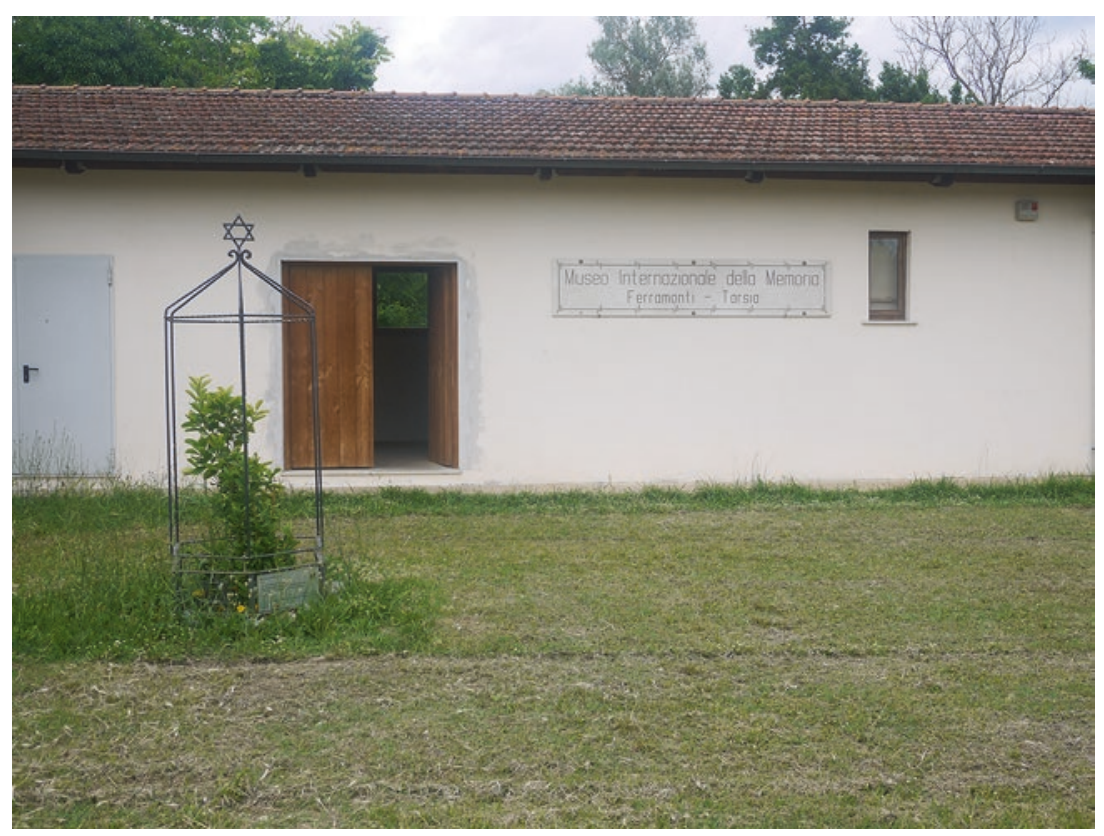

Fig. 4.7 The Museum of Memory on the site of the Ferramonti camp, Tarsia, Italy, May 2018 (cl. Marc Brightman)

'countermonument', which 'does not console or reassure-it does not heal. On the contrary, it “torments” its neighbours' (James E. Young, in Homans 2000: 22-23) with the reality of death at the threshold of Europe. But there are reasons for thinking that its role is more ambivalent. The annual celebration of the Liberation at Ferramonti portrays the concentration camp as a relic of resistance, rather than of oppression, in its own right. The reason for this is that the concentration camp was not a site of extermination; nor was it, in practice, a site for deportation. It was designed to be a holding center for Jews and other minorities and political prisoners from all over the continent, who were supposed to be deported to Nazi death camps. The camp officials are said to have continually put off German requests to deport interns of Ferramonti to Germany. It was the first concentration camp to be liberated by the Allies in 1943, and in contrast to what they would find further north, it looked to them more like a village than a prison (it had synagogues, a hospital, school and a 
nursery) — indeed many inmates stayed there, under their own administration, until the end of the war. To add to this image of Ferramonti as a place of refuge, after the liberation it also became a refugee camp. The site of Ferramonti therefore has complex affective resonances (Stewart 2012): as representative of concentration camps in general, it evokes the horror of the holocaust and of fascism; yet for those who are aware of the relatively humane way in which it was managed, it evokes the values of the resistance and the liberation, which were to be institutionalized in the Republic and in international human rights instruments. Political actors such as rural mayors and legal prosecutors invoke these values when they justify the moral and legal rationale for the recovery, identification and burial of unidentified migrant remains in Italy today.

\section{Anthropology and the Death of Strangers}

For there to be hospitality, notes Patrice Ladwig, citing Derrida, Simmel and van Gennep, 'there must be a door...there must be a threshold' (2012: 93), and indeed what clearer threshold-an ontological one at that - than the threshold between life and death? Yet few authors have taken comparisons between the threshold of life and death and the threshold crossed by the visiting stranger (or indeed the border) beyond the level of analogy or metaphor. Robert Hertz's observation, in his seminal study of death based on data from the south Pacific, that 'the death of a stranger, a slave, or a child will go almost unnoticed; it will arouse no emotion, occasion no ritual' (1960: 76) has remained largely unchallenged, with the vast majority of subsequent scholarship in the anthropology of death focusing on mortuary practices for members of the community. The figure of the dead stranger has most often taken the form of the lost soul, who suffers from having died a 'bad death', leading anthropologists to document the widespread perception of the 'danger of the unincorporated dead': typically, wandering spirits, 'for whom no rites were performed' could act as 'hungry ghosts' who 'yearn to be reincorporated into the world of the living, and since they cannot be, they behave like hostile strangers' (Abramovitch 2001: 3272). Exploring one such case of those 'who have died a bad or violent death away from home' (2012: 90), Ladwig notes how Lao people care for 'initially anonymous ghosts' through 'hospitality and the establishment of a kinship bond' through material action - in this case feeding, which transforms the 'radical alterity of ghosts' into 'an integral part of the social world' (2012: 91). The Lao 
practice of giving sweet food to revenants on a specific day of the year, feeding ghostly strangers to turn them into kin, is worth comparing with the Sicilian tradition whereby deceased kin return on the eve of All Souls' Day bringing gifts and sweets for children and where families bring flowers to their tombs the following day (Camilleri 2001). In both cases the ritual serves to reintegrate the souls of the dead into society; or rather (following Benveniste's definition of community as the product of mutual exchange, 2016), the ritual maintains a cycle of transactions that perpetuate the dead's place in the community (cf. Malcolm n.d.).

Such ghostly encounters share with classical anthropological discussions of mortuary practices for community members the themes of kinship and social (re-)integration (Bloch and Parry 1982). This is not usually the case with the other significant area in which the treatment of the remains of dead strangers has been discussed, which is that of enemies killed in warfare. Lowland South America is one exception, where the ritual killing and disposal of the remains of enemies was a fundamental element in social reproduction, and among the Tupinamba, to be killed by the enemy was considered the 'good death' (Viveiros de Castro 1992: 274; Allard and Taylor 2016: 62). Simon Harrison notes that despite the fact that the Geneva Conventions of 1949 declare that war dead must be 'identified and buried in marked and properly maintained graves so as to permit their repatriation after hostilities have ended' (2012: 1), ideologies of race nevertheless intuitively structure attitudes and behavior towards the dead body... they are, after all, ideologies which naturalize social inequalities by misrepresenting them as founded in the physical body and in human biology' (2012: 5). These ideologies of race are often deeply embedded as colonial legacies in attitudes toward foreign bodies, and they continue to influence the cultural attitudes of many Italians toward migrants from the global south (Brioni and Bonsa Gulema 2018; Scego and Bianchi 2014). As noted above, the Geneva Convention does not apply to those who die on the migrant trail, and there are therefore considerably fewer legal mechanisms to prevent racial prejudice from having a free rein in the treatment of dead migrants.

The enduring importance attached to the place and manner of burial and the decomposition or cremation of remains testifies to the fact that personhood is a more complex affair than an opposition between the material container and a spiritual identity. Yet many authors seem to share Hertz's assumptions about the immateriality of the social person: for him, death 'destroys the social being grafted upon the physical individual and 
to whom the collective consciousness attributed great dignity and importance' (1960: 77). The role of the materiality of personhood is acknowledged by the current teaching of the Catholic Church that 'the bodies of the dead must be treated with respect and charity in the faith and hope of resurrection. The burial of the dead is a work of bodily mercy; it gives honor to the sons of god, temples of the Holy Spirit' (Catechism of the Catholic Church n.d.: 2300), and the Vatican's support for the Tarsia cemetery (in which Franco Corbelli takes considerable pride) is certainly informed by this view. This Catholic teaching undermines the broad association drawn between Western, European or 'naturalist' ontologies and the notion of the immateriality of the soul and which Marilyn Strathern traces to Victorian England, as expressed by E.B. Tylor, who she argues was wrong to think that immortality was linked to immateriality (Strathern 2018). In many cases 'the body is not only divisible but also shareable, and...its fragmentation may form part of a process that is seen as not only normal but also as necessary to the continuity and regeneration of life' (Ramos 2010: 32), and we suggest that the personhood of the deceased persists in the material remnants following death, even when these may be broken up and dispersed, though in such cases the very disintegration of the person poses further questions. Not least among these is the problem of perspective and control, for the discourses surrounding the mortuary practices for dead migrant are dominated by their hosts at every stage of the chaine opératoire, from recovery through forensic and administrative processing to burial. When the Italian hosts dominate these practices, even when the corpses are returned to the sending communities, as occurred with the victims of the Kateri i Radës, the bereaved relatives feel detached from them and are unable to conduct the proper rituals.

\section{Conclusion: Scales of Remembrance}

The Italian government promised a state funeral for the migrants who died in the 2013 disaster but in the end organized an ill-conceived memorial service in Agrigento to which the survivors were not invited. The event was discredited in particular by the government's gesture of inviting representatives from the Eritrean embassy-thus generating a cruel farce, whereby the victims of the boat disaster were to be officially commemorated by delegates of the state that they had been fleeing (Scego and Bianchi 2014). Eritrea's status as a former Italian colony and the role of this colonial connection in the history of the Eritrean community in Italy 
are part of a colonial historical background that lurks beneath the surface of competing anti-immigrant and anti-fascist public sentiments. The event backfired thanks to the protests of the Eritrean relatives of the dead, and the refusal of the mayors of Lampedusa and Agrigento to participate, on the implicit grounds that remembrance and hospitality are morally entangled with each other. The collusion of the Italian and Eritrean states in this inhospitable act of remembrance served to resurrect the ghosts of colonialism, as a reminder of the deeper historical responsibility borne by European nations for the postcolonial trajectories of African societies. For similar reasons Albanian politicians were criticized by relatives of the Kateri i Radës missing for making little attempt to memorialize dead community members, leaving the task up to families and church councils. They accuse the Italian and Albanian governments of neglecting their promises to finance and build a monument to the dead, to focus instead on colluding in trade deals which benefit only the corrupt politicians themselves. As one informant declared, 'the Albanians have a deep affection for Italian people, but they hate the Italian government, the Italian government is fascist'. Furthermore both of these cases underline the temporary status of the guest-by inviting Eritrean officials to participate in the ceremony at Agrigento, the Italian state symbolically returned the dead migrants to their place of origin and the bodies recovered from the Kateri i Radës were sent back to Albania. But in both cases Italy proved a bad host, because the 'return' of the guests was not acceptable or meaningful to their relatives. This highlights one of the problems of hosting the dead: the law of hospitality implies that host-guest relations should be temporary, but dead strangers may remain indefinitely. Memorialization can be thought of as an attempt, which sometimes fails, to overcome this difficulty either through unconditional hospitality or through symbolic restitution.

It is families, religions and community organizations rather than governments that have initiated the acts of naming that have played a special role after mass atrocities in the past. This has been the key strategy of the Mothers of Plaza de Mayo in Argentina, and Enrico Calamai, who was Italian consul in Buenos Aires in 1972-1977 during the Argentine military regime, has underlined how Europe is producing 'its own desaparecidos, [migrants] left to die and made invisible by politics of elimination and memory-erasure' (Gualtieri 2018: 22). The ritual naming of the disappeared bears witness to the injustice of their absence. This 'necronominalism' (Laqueur 2015), inscribing and reading or speaking the names of the dead, invokes 'the individuals indexed by the names and fixes those lives 
into collective memory' (Hodges 2019). Naming dead strangers poses a difficulty, for the anonymous dead can be hosted as part of fraternal humanity; the named stranger is marked as an other, whose kin are foreign. The act of naming, moreover, is carried out by the host, together with the treatment of the corpse and the eventual burial. The forensic work of the Labanof seeks to reconstruct identities and names to show that the dead were people, with interconnected lives, families, friends, ambitions. Their stories can re-ground them in the mutually entangled histories of the different shores of the Mediterranean. Yet they also highlight an unresolved problem, which is that of setting the rules of hospitality. As we have seen, different actors presenting themselves as hosts compete to decide how migrant bodies should be treated and what meanings should be attached to them. One of the features of hospitality however is that the relations between host and guest can become especially tense when they do not agree upon the rules of hospitality (Shryock 2012). Migrant human remains are on one level giving rise to the emergence of new forms of hospitality, such as new forensic protocols and new kinds of cemeteries. On another level, however, there is little to indicate that the bereaved relatives have any say in making the rules.

\section{Notes}

1. This song refers to the 'Tragedy of Otranto'; on 28 March 1997, a fishing boat called the Kateri i Radës, carrying 122 civilians, left the town of Vlora in southern Albania to cross the Strait of Otranto toward Italy. It was intercepted and rammed by an Italian navy corvette and sank in a matter of minutes, causing the death of over 81 people, 24 of whom were never recovered (Leogrande 2010; Pistrick 2015).

2. Lampedusa is the largest of the Pelagic islands. It is part of the autonomous region of Sicily but is located close to the North African coast. Having been occupied or colonized in turn by Phoenicians, Arabs, British and Bourbons, its population is largely a fishing community isolated from the mainland and neglected by the state, despite the establishment of a permanent military base in the 1970s and the more recent establishment of migrant reception infrastructure (Centro di Primo Soccorso e Accoglienza [First Aid and Reception Centre], CPSA). During the 1990s it became a seasonal tourist destination as well as a prominent part of the Mediterranean 'migration archipelago' receiving a sizeable share of the boats carrying asylum-seekers rescued at sea following increasingly dangerous sea crossings in the Channel of Sicily. 
3. Cf. Quagliariello this volume.

4. Most of the bodies recovered from the 11 th October shipwreck were taken to Malta (Cattaneo 2018: 82-83).

5. http://www.interno.gov.it/it/notizie/3-ottobre-e-giornata-nazionalememoria-vittime-dellimmigrazione.

6. On 4 March 2018, general elections were held in Italy which led to the creation of the current coalition government between two parties located on the populist and far right of the political spectrum: the Lega and the Five Star Movement. Among the first measures taken by the government were highly restrictive and anti-immigration policies directed at closing off Italian land and sea borders and targeting migrants already present in the country.

7. Text taken from the video available at https://www.agi.it/video/lampedusa_ricordo_strage_migranti_2013-4442921/video/2018-10-03/.

8. Italian colonialism in Africa (1882-1960) and Albania (1939-1943) left enduring cultural marks and social structural legacies. Many colonial subjects became Italian citizens. A significant number of migrants came to Italy from Eritrea, Ethiopia and Somalia from the 1970s, and thousands of Italians still resided in Libya decades after national independence. After the communist regime in Albania fell in the early 1990s, many Albanians migrated to Italy.

9. A detailed account of the various kinds of mobilization and tensions among local communities, survivors and relatives to identify and mourn for the dead is beyond the scope of this chapter, as is the broader context of hospitality (and inhospitability) for survivors. For examples of the latter, see Kobelinsky (2019), Pillant (2019), Souiah (2019) and Zagaria (2019).

10. The Ufficio del Commissario Straordinario del Governo per le Persone Scomparse (UCPS) was created in 2007, and its work was extended to the victims of international migration recovered at sea in 2012. The UCPS, being a ministerial office located within the Ministry of the Interior, is headed by an appointed commissioner and is subject to the Ministry's authority (http://www.interno.gov.it/it/ministero/commissario-straordinario-governo-persone-scomparse).

11. Antigone, a recurring figure in political philosophical discussions of biopolitics, positioned herself as a 'stranger', by choosing to define herself as a

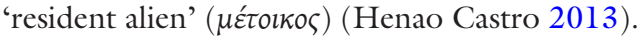

12. For example, the blog of journalist and writer Gabriele del Grande http:// fortresseurope.blogspot.com/.

13. In contrast to other mass disasters (such as natural disasters or aeroplane crashes), and as Cattaneo has pointed out (Cattaneo and D'Amico 2016), the international community of forensic experts has not rushed to the scene following migrant shipwrecks, and instead Italian experts have orga- 
nized themselves, often working on a voluntary basis, to carry out the necessary tasks.

14. In the case of the Kateri i Radës wreck, the third stage is replaced with the return of the bodies to Albania. With apologies to material culture scholars, we use the notion of chaîne opératoire loosely here, as a rhetorical device, and our objective is not to offer a systematic description of the chaine opératoire in question (a thoroughly worthwhile task beyond the scope of this chapter) but rather merely to sketch its outlines.

15. '[T] person?" and "what counts as sufficient proof of one's identity?" were ones that I had debated many times before’ (2006a: 2).

16. http://www.labanof.unimi.it/.

17. Petrović-Šteger has written, how, as well as helping to detect and prosecute crimes, forensic experts in technical interventions into the landscape of mass graves in post-conflict Yugoslavia crucially redefined the value of such spaces. In sieving the soil, they erased some while preserving other traces of the recent past, ritually cleansing the land (2006b). This 'sieving' of the remains brings forensics closer to the two-stage burial practices common to many traditional mortuary practices (Hertz 1960; Bloch and Parry 1982): the separation of the soft from the hard parts, the flesh from the bone, is evoked by the forensic salvaging of material that is particular, meaningful or which embodies a connection to others.

18. Although, unlike war cemeteries and memorials (Prost 2011), those for migrants attract few visitors.

19. Another case that has been presented as a 'migrants' cemetery' in Calabria is that of Armo, a village outside Reggio Calabria. Under the initiative of the mayor and the previous parish priest, 45 migrants who died at sea were buried there in 2016. Although the charity Caritas aspires to transform it into a project similar to Tarsia, it has so far operated in a similar way to other cemeteries that host migrants who died on their journeys, albeit on a larger scale, and the expanded area of the cemetery where the shipwrecked migrants are buried also contains the tombs of local people.

\section{REFERENCES}

Abramovitch, H. 2001. Death, Anthropology Of. In International Encyclopaedia of the Social and Behavioural Sciences, ed. J. Wright. Amsterdam: Elsevier.

Albahari, M. 2015. Crimes of Peace: Mediterranean Migrations at the World's Deadliest Border. Philadelphia: University of Pennsylvania Press.

Allard, O., and A.-C. Taylor. 2016. Traitement des cadavres et mémoire des personnes en Amazonie. In Qu'est-ce qu'une sépulture? Humanités et systèmes funéraires de la préhistoire à nos jours: XXXVIe rencontres internationales 
d'archéologie et d'histoire d'Antibes, ed. M. Lauwers and A. Zemour, 55-68. Antibes: Editions APDCA.

Anstett, E., and G. Gatti. 2018. Introduction de l'Atelier Sangs Politiques. Politika.io/fr.

Ben-Yehoyada, N. n.d. Is the Mediterranean's Seabed a Grave? Underwater Relics and the Reach of Relatedness. Unpublished manuscript.

Benveniste, E. 2016. Dictionary of Indo-European Concepts and Society. Chicago: University of Chicago Press.

Black, S. 2018. All that Remains: A Life in Death. Harmondsworth: Penguin.

Bloch, M., and J. Parry, eds. 1982. Death and the Regeneration of Life. Cambridge: Cambridge University Press.

Boret, S., S. Long, and S. Kan, eds. 2017. Death in the Early 20th Century: Authority, Innovation and Mortuary Rites. New York: Palgrave Macmillan.

Brioni, S., and S. Bonsa Gulema. 2018. Introduction. In The Horn of Africa and Italy: Colonial, Postcolonial and Transnational Encounters, 1-44. Oxford: Peter Lang.

Camilleri, A. 2001. Il giorno che i morti persero la strada di casa. In I racconti quotidiani, 82-83. Libreria dell'Orso.

Casid, J. 2018. Necropolitics at Sea. In Migration and the Contemporary Mediterranean: Shifting Cultures in Twenty-First Century Italy and Beyond, ed. C. Gualtieri, 193-214. Oxford: Peter Lang.

Catechism of the Catholic Church. n.d.. http://www.vatican.va/archive/catechism_it/p3s2c2a5_it.htm

Cattaneo, C. 2018. Naufraghi senza volto. Dare un nome alle vittime del Mediterraneo. Milan: Cortina.

Cattaneo, C., and M. D'Amico, eds. 2016. I diritti annegati: I morti senza nome del Mediterraneo. Milano: Franco Angeli.

Crossland, Z. 2015. Epilogue. In Necropolitics: Mass Graves and Exhumations in the Age of Human Rights, ed. F. Ferrándiz and A. Robben, 240-252. Philadelphia: University of Pennsylvania Press.

De León, J. 2015. The Land of Open Graves: Living and Dying on the Migrant Trail. Oakland: University of California Press.

Elhariry, Y., and E. Tamalet Talbayev. 2018. Critically Mediterranean: An Introduction. In Critically Mediterranean: Temporalities, Aesthetics, Deployments of a Sea in Crisis, ed. Y. Elhariry and E. Tamalet Talbayev. Palgrave Macmillan.

Ferrándiz, F., and A. Robben. 2015. Introduction: The Ethnography of Exhumations. In Necropolitics: Mass Graves and Exhumations in the Age of Human Rights, ed. F. Ferrándiz and A. Robben, 1-38. Philadelphia: University of Pennsylvania Press.

Geertz, C. 1957. Ritual and Social Change: A Javanese Example. American Anthropologist 59 (1): 32-53. 
Ghidini, L. 2018 Naufraghi Senza Volto: “È Necessario Identificare I Morti in Mare". Radio Popolare, November 29.

Glynn, I., and J. Olaf Kleist. 2012. Introduction: The Memory and Migration Nexus: An Overview. In History, Memory and Migration: Perceptions of the Past and the Politics of Incorporation, ed. I. Glynn and J.O. Kleist, 3-32. New York: Palgrave Macmillan.

Gregorič Bon, N. 2017. Movement Matters: The Case of Southern Albania. Ethnologie Française XLVII (2): 301-308.

Gualtieri, C. 2018. Migration and the Contemporary Mediterranean: Shifting Cultures in Twenty-First Century Italy and Beyond. Oxford: Peter Lang.

Harrison, S. 2012. Dark Trophies: Hunting and the Enemy Body in Western War. New York: Berghahn.

Henao Castro, A. 2013. Antigone Claimed: “I Am a Stranger!" Political Theory and the Figure of the Stranger. Hypatia 28 (2): 307-322.

Hertz, R. [1905] 1960. A Contribution to the Study of the Collective Representation of Death. In Death and The Right Hand, trans. Rodney and C. Needham. Glencoe: The Free Press.

Hodges, Adam. 2019. Speak the Names of Those Who Were Lost. Anthropology News. https://doi.org/10.1111/AN.1139

Homans, P. 2000. Symbolic Loss: The Ambiguity of Mourning and Memory at Century's End. Charlottesville: University Press of Virginia.

Hunter, A., and E. Ammann. 2016. End-of-Life Care and Rituals in Contexts of Post-migration Diversity in Europe: An Introduction. Journal of Intercultural Studies 37 (2): 95-102.

IOM. 2019. Recorded Migrant Deaths by Region. Missing Migrants. https:// missingmigrants.iom.int

Kobelinsky, C. 2019. Les traces des morts: gestion des corps retrouvés et traitement des corps absents à la frontière hispano-marocaine. Critique Internationale 83: 21-39.

Ladwig, P. 2012. Visitors from Hell: Transformative Hospitality to Ghosts in a Lao Buddhist Festival. Journal of the Royal Anthropological Institute (N.S.): S90-S102.

Laqueur, T. 2015. The Work of the Dead. Princeton: Princeton University Press.

Last Rights. 2017. The Dead, the Missing and the Bereaved at Europe's International Borders: Proposal for a Statement of the International Legal Obligations of States. Accessed April 22, 2019. https://www.ohchr.org/ Documents/Issues/Migration/36_42/TheLastRightsProject.pdf

Lemonnier, P. 1976. La description des chaînes opératoires: contribution à l'analyse des systèmes techniques. Techniques et culture 1: 100-151.

Leogrande, A. 2010. Il naufragio. Morte nel Mediterraneo. Milano: Feltrinelli.

Malcolm, H. n.d. How Should We Dispose of the Dead, and How Should We Mourn Them? Accessed April 22, 2019. http://yale.academia.edu/ HannahMalcolm 
Merli, C., and T. Buck. 2015. Forensic Identification and Identity Politics in 2004 Post-tsunami Thailand: Negotiating Dissolving Boundaries. Human Remains and Violence 1 (1): 3-22.

Navaro-Yashin, Y. 2009. Affective Spaces, Melancholic Objects: Ruination and the Production of Anthropological Knowledge. Journal of the Royal Anthropological Institute 15: 1-18.

Perl, G. 2016. Uncertain Belongings: Absent Mourning, Burial, and Post-mortem Repatriations at the External Border of the EU in Spain. Journal of Intercultural Studies 37 (2): 195-209.

Petrović-Šteger, M. 2006a. The Ways of Dead Bodies: Dealing with Human Remains in Postconflict Serbia and Tasmania. PhD thesis, Cambridge University.

- 2006b. Anatomizing Conflict-Accommodating Human Remains. In Social Bodies, ed. H. Lambert and M. MacDonald. Oxford and New York: Berghahn.

Pillant, L. 2019. "Not in my cemetery". Le traitement des corps de migrants morts à la frontière orientale de la Grèce. Critique Internationale 83: 41-59.

Pistrick, E. 2015. Performing Nostalgia: Migration, Culture and Creativity in South Albania. London and New York: Routledge.

Prost, A. 2011. Les cimetières militaires de la Grande Guerre, 1914-1940. Le Mouvement Social 237: 135-151.

Qui Cosenza. 2019. 25 Aprile a Ferramonti Simbolo di Umanità anche con il Cimitero dei Migranti. https://www.quicosenza.it/news/provincia-cosenza/ 289740-25-aprile-a-ferramonti-simbolo-di-umanita-anche-con-il-cimiterodei-migranti

Ramos, G. 2010. Death and Conversion in the Andes: Lima and Cuzco, 1532-1670. Notre Dame: University of Notre Dame Press.

Reuters. 2017. Migrant Deaths in the Sahara Likely Twice Mediterranean Toll: U.N. Accessed April 29, 2019. https://www.reuters.com/article/us-europemigrants-sahara/migrant-deaths-in-the-sahara-likely-twice-mediterraneantoll-u-n-idUSKBNICH21Y.

Robins, S. 2019. The Affective Border: Missing Migrants and the Governance of Migrant Bodies at the European Union's Southern Frontier. Journal of Refugee Studies. fey064. https://doi.org/10.1093/jrs/fey064

Rojas-Perez, I. 2017. Mourning Remains: State Atrocity, Exhumations, and Governing the Disappeared in Peru's Postwar Andes. Stanford: Stanford University Press.

Sarnelli, L. 2015. The Gothic Mediterranean: Haunting Migrations and Critical Melancholia. Journal of Mediterranean Studies 24 (2): 147-165.

Scego, I., and R. Bianchi. 2014. Roma Negata: Percorsi Postcoloniali nella Città. Roma: Ediesse. 
Shryock, A. 2012. Breaking Hospitality Apart: Bad Hosts, Bad Guests, and the Problem of Sovereignty. In The Return to Hospitality: Strangers, Guests, and Ambiguous Encounters, ed. M. Candea and G. da Col. Journal of the Royal Anthropological Institute, Special issue, pp. S20-S33.

Smith, L. 2013. "Genetics is a Study in Faith": Forensic DNA, Kinship Analysis, and the Ethics of Care in Post-conflict Latin America. Scholar \& Feminist Online 11 (3): 221.

Souiah, F. 2019. Corps absents: des fils disparus et des familles en lutte? Le cas des migrants tunisiens. Critique Internationale 83: 87-100.

Stewart, Charles. 2012. Dreaming and Historical Consciousness in Island Greece. Cambridge, MA: Harvard University Press.

Stierl, M. 2016. Contestations in Death-The Role of Grief in Migration Struggles. Citizenship Studies 20 (2): 173-191. https://doi.org/10.1080/1362102 5.2015.1132571.

Strathern, M. 2018. Souls in Other Selves, and the Immortality of the Body. Foerster Lecture on the Immortality of the Soul. California: University of Berkeley, April 17.

Tapella, A., G. Mirto, and T. Last. 2016. Deaths at the Borders. From Institutional Carelessness to Private Concern. Research Notes from Italy. In Trasformazione 5 (1): 57-64.

Tung, T. 2014. Agency, 'Til Death Do Us Part? Inquiring about the Agency of Dead Bodies from the Ancient Andes. Cambridge Archaeological Journal 24: 437-452.

Varley, E., and S. Varma. 2018. Spectral Ties: Hospital Hauntings Across the Line of Control. Medical Anthropology 37 (8): 630-644. https://doi.org/10.108 0/01459740.2018.1490280.

Vatican News. 2018. Testo integrale del dialogo del Papa con giovani e anziani all'Augustinianum (23 ott). Vatican News. https://www.vaticannews.va/it/ papa/news/2018-10/testo-integrale-dialogo-papa-francesco-giovanianziani.html.

Viveiros de Castro, E. 1992. From the Enemy's Point of View: Humanity and Divinity in an Amazonian Society. Chicago: University Press.

Wagner, S. 2013. The Making and the Unmaking of an Unknown Soldier. Social Studies of Science 43 (5): 631-656.

Zagaria, V. 2019. "Une petite histoire au potentiel historique fort". La fabrique d'un cimitère de migrants inconnus dans le sud-est tunisien. Critique Internationale 83: 61-85. 
Open Access This chapter is licensed under the terms of the Creative Commons Attribution 4.0 International License (http://creativecommons.org/licenses/ by $/ 4.0 /$ ), which permits use, sharing, adaptation, distribution and reproduction in any medium or format, as long as you give appropriate credit to the original author(s) and the source, provide a link to the Creative Commons licence and indicate if changes were made.

The images or other third party material in this chapter are included in the chapter's Creative Commons licence, unless indicated otherwise in a credit line to the material. If material is not included in the chapter's Creative Commons licence and your intended use is not permitted by statutory regulation or exceeds the permitted use, you will need to obtain permission directly from the copyright holder. 